\title{
The prevalence and treatment of hypertension in the elderly population of the Mexican Institute of Social Security
}

Carmen García-Peña, M.D., Ms.C., Ph.D., ${ }^{(1)}$ Margaret Thorogood, Ms.C., Ph.D., ${ }^{(2)}$ Sandra Reyes, M.D., Ms.C., Ph.D., Jorge Salmerón-C astro, M.D., Ms.C., Ph.D., ${ }^{(4)}$ Carlos D urán, M.D., Ms.C. .1)

García-Peña C,Thorogood M, Reyes S, Salmerón-Castro J, Durán C. The prevalence and treatment of hypertension in the elderly population of the Mexican Institute of Social Security. Salud Publica Mex 2001;43:415-420.

The English version of this paper is available at: http://www.insp.mx/salud/index.html

\begin{abstract}
A bstract
Objective.To assess the prevalence and treatment of high blood pressure among elderly people in Mexico. Material and MethodsA cross-sectional study was conducted from February to July 1998 among the elderly people covered by the Instituto Mexicano del Seguro Social (IMSS) healthcare services in Mexico City. The study population consisted of 4777 subjects aged 60 years and over, selected from a cohort of 5433 people, representative of the population of Mexico City. Trained nurses carried out three blood pressure measurements at home. Diagnosis of high blood pressure was established if systolic pressure was equal to or higher than $160 \mathrm{mmHg}$, and/or diastolic pressure was equal or higher than $90 \mathrm{mmH} \mathrm{g}$, or by self-report of a medical diagnosis of hypertension. D emographic and risk factor information was also collected. Results A total of 4 777 subjects were screened; 2036 (43\%) of them reported that they had been previously diagnosed as hypertensive. 0 f these, 1954 (96\%) were already on phar macological treatment. A further $273(5.7 \%)$ subjects were found to be hypertensive at screening. Among those receiving treatment, $1399(68.5 \%)$ had a blood pressure reading of less than $160 / 90 \mathrm{mmHg}$, and this was also the case for $59(72 \%)$ of
\end{abstract}

\section{García-Peña C,Thorogood M, Reyes S,}

Salmerón-Castro J, Durán C.

Prevalencia y tratamiento

de hipertensión en ancianos

en el Instituto Mexicano del Seguro Social.

Salud Publica Mex 2001;43:415-420.

El texto completo en inglés de este artículo está

disponible en: http://www.insp.mx/salud/index.html

\section{Resumen}

Objetivo. Determinar la prevalencia y el tratamiento de la hipertensión arterial en ancianos en México. Material y métodos. De enero a julio de 1998, se llevó a cabo un estudio transversal en ancianos derechohabientes del Instituto Mexicano del Seguro Social. La población de estudio consistió de 4777 ancianos, seleccionados de una cohorte representativa de 5433 sujetos residentes en el Distrito Federal. Enfermeras entrenadas midieron tres veces la presión arterial en el do micilio de los sujetos de estudio. Se diagnosticó hipertensión arterial si la presión sistólica era igual o mayor a $160 \mathrm{~mm} \mathrm{Hg}$ y/o si la presión diastólica era igual o mayor a $90 \mathrm{~mm} \mathrm{Hg}$ o por auto reporte de un diagnóstico médico.Se colectó también información demográfica y sobre factores de riesgo. Resultados Un total de 4777 sujetos fueron estudiados y 2036 (43\%) reconocieron un diagnóstico previo de hipertensión; de esos, 1954 (96/) se encontraban bajo tratamiento farmacológico y $273(5.7 \%)$ fueron hallazgo del tamizaje. El $68.5 \%(n=1399)$ de aquellos que recibían tratamiento y $59(72 \%)$ de los que reportados como hipertensos no recibían tratamiento, tuvieron una presión arterial de menos de 160/90 $\mathrm{mm} \mathrm{Hg}$. De aquellos

This study was funded by the $\mathrm{N}$ ational Council of Science and Technology (Conacyt) and the Mexican Institute of Social Security (IMSS).

(1) Health Services Research Area. Research Coordination. Mexican Institute of Social Security, Mexico City, Mexico.

(2) Health Promotion Research U nit. London School of Hygiene and Tropical Medicine, London, United Kingdom.

(3) Medical Research Unit on Ageing, D elegación Q uerétaro. Mexican Institute of Social Security, Q ueretaro, Mexico.

(4) Epidemiological and Health Services Research Unit. Mexican Institute of Social Security, Mexico City, Mexico.

Received on: September 20,2000 • Accepted: N ovember 6,2000

Address reprint requests to: Dra. Ma. del Carmen García-Peña. División de Investigación Epidemiológica y en Servicios de Salud, Edificio Bloque "B", Cuarto piso, Unidad de Congresos, Centro Médico N acional Siglo XXI. Avenida Cuauhtémoc 330, colonia D octores, 06125 México D.F., México. E-mail: mcgp1@ terra.com.mx 
the known hypertensives not on treatment. A single drug was used by 1556 (79.6\%) of those on treatment. Risk factors for hypertension were more frequent in the hypertensive group (pf 0.05). Conclusions. Almost half of the elderly population is hypertensive, most of them are already on treatment, but about one third of those on treatment do not have an adequate control of high blood pressure. The English version of this paper is available to o at: http://www.insp.mx/salud/index.html

Keywords: hypertension; prevalence; aged; chronic diseases; Mexico en tratamiento, 1556 (79.6\%) tomaban un solo medicamento. La frecuencia de factores de riesgo fue más alta en el grupo de hipertensos $(p \leq 0.05)$. Conclusiones Casi la mitad de la población anciana estudiada es hipertensa, mucha de ella en tratamiento; sin embargo, una tercera parte de éstos no tienen un adecuado control de la presión arterial. El texto completo en inglés de este artículo está también disponible en: http://www.insp.mx/salud/index.html

Palabras clave: hipertensión; prevalencia; anciano; enfermedades crónicas; México
$\mathrm{T}$ he increasing proportion of the population that is aged 60 years or more and the accompanying growing prevalence of non-communicable diseases are important health issues in Mexico. ${ }^{1}$ The Mexican Institute of Social Security, the most important healthcare provider in Mexico, offers medical care to a large proportion of people aged 60 years or more. ${ }^{2}$ Mortality and morbidity from non-communicable disease have increased substantially in Mexico between 1922 and 1995. ${ }^{3}$ In that period, the percentage of all deaths attributed to non-communicable diseases increased from $11.8 \%$ to $55 \%$. The incidence of hypertensive disease has increased in Mexico by $40 \%$, while in the United Kingdom it fell by $24 \%$ during the period 1986-1995. ${ }^{4,5}$

Research has established the important role of high blood pressure and its associated cardiovascular conditions, in the morbidity, mortality, and disability rates of the elderly population. High blood pressure in the elderly has a high impact on the economy and on the quality of life of individuals; it also has important implications for institutional resource expenditures.$^{6-8}$ Consideration of effective interventions requires the assessment of the magnitude and extent of the burden of hypertensive disease in the elderly. To this end, this study was conducted to describe the prevalence of hypertension among the elderly IMSS population in Mexico City.

\section{Material and Methods}

The study population was a random sample of 5433 subjects aged 60 years and over, representing the IMSS population of Mexico City. Study subjects were originally selected for a study of health needs, health services utilization, and cost of health services. ${ }^{2}$ This cohort was selected by multistage random sampling, first by Family Medicine Center (12 Centers selected out of 43), and then by age-stratified sampling within the population served by each Family Medicine Center (approximately 450 participants from each center, selected from the assigned population). Specific sample fractions by age were used to guarantee selection of enough subjects in each age group. Screening for high blood pressure began one year after the cohort was assembled, and took place from February to July 1998.

Fifteen trained nurses obtained blood pressure readings, after obtaining informed consent and checking that it was an appropriate time to measure blood pressure. Nurses did not measure the blood pressure if the subject had taken anti-hypertensive drugs in the last 2 hours or had exercised, drunk coffee, or smoked in the last hour. ${ }^{9}$ In such cases, fieldwork personnel made another appointment.

Data on socio-demographic variables were collected by direct interviews using a structured questionnaire. Self-reported data were collected on medical history of diabetes, angina pectoris, acute myocardial infarction, renal failure, and hypercholesterolemia, as well as on self-reported smoking and physical activity.

Blood pressure was measured with a Takeda mercurial sphygmomanometer. Special cuffs for thicker arms were used whenever appropriate and the equipment was calibrated regularly. The nurses checked daily that the mercury column was at zero millimeters before readings. Three blood pressure measurements were taken, two when the participant was seated and once after standing for at least two minutes. Each of these measurements was separated by five minutes of relaxing. Systolic blood pressure was set at the first Korotkoff sound, while diastolic blood pressure was read when the sound disappeared 
completely (phase V of Korotkoff sounds). The cuffdeflation rate was $2 \mathrm{~mm} /$ second and the reading made to the nearest $2 \mathrm{~mm} \mathrm{Hg} .{ }^{9,10}$ Nurses recorded all the measurements and the mean of the two seated blood pressure readings was calculated using a computer. The standing blood pressure figures were used to detect hypotension. At the end of the visit, the nurse gave participants a written result of the blood pressure readings and advised them to visit their family physicians.

Hypertension was diagnosed when either the mean seated systolic blood pressure was equal to or higher than $160 \mathrm{~mm} \mathrm{Hg}$, or the mean diastolic blood pressure was equal to or higher than $90 \mathrm{~mm} \mathrm{Hg}$, or both.

Standing blood pressure was used to diagnose hypotension. Nurses applied the Osler's manoeuvre ${ }^{11}$ in all the participants with blood pressure readings above $160 / 90 \mathrm{~mm} \mathrm{Hg}$. Those found to have a positive Osler's manoeuvre were not defined as hypertensive. Subjects with a previous diagnosis of hypertension or high blood pressure made by a medical doctor were defined as hypertensive. Treatment of hypertension was defined as self-reported current use of a prescribed medication affecting blood pressure. Participants who had a personal history of hypertension but who reported that they were not currently taking antihypertensive drugs were defined as hypertensive.

Data were entered in electronic format using an optical reader and analyzed using SPSS version 6.0. Statistical analysis consisted of descriptive statistics and difference of proportions. The analysis was carried out in two ways: first assuming an unweighted sample and then with the sample weighted by age group sample fractions.

The proposal was approved by the Research Committee of the Mexican Institute of Social Security Research Coordination and by the Ethics Committee of the London School of Hygiene and Tropical Medicine.

\section{Results}

Two hundred and sixteen (3.9\%) participants had died before the hypertension prevalence study began. Fifty-four people $(0.9 \%)$ refused to participate in the study and 386 people $(7.1 \%)$ could not be found. Thus, the total non-response rate from the original sample was $12.1 \%$, leaving 4777 participants who were screened. Of these, a total of $2036(43 \%)$ reported that a doctor had diagnosed them as hypertensive and 1954 (96\%) were on antihypertensive therapy. A further $273(5.7 \%)$ subjects were found to be hypertensive at screening, as defined in the previous section. Distributions of prevalence by gender, adjusted by age, are presented in Table I. The prevalence is higher in females, except in the group of newly-diagnosed patients. One hundred and twenty nine participants had a positive Osler manoeuvre, and therefore were excluded from the hypertensive group because of possible pseudohypertension. In total, 2309 participants $(48.3 \%)$ were diagnosed as hypertensive. This proportion did not change when the analysis was carried out as a weighted sample.

Table II shows selected demographic, lifestyle, and clinical variables, by the presence or absence of

Table I

Prevalence of hypertension by gender, adjusted by age group. Mexico City, Mexico, 1998

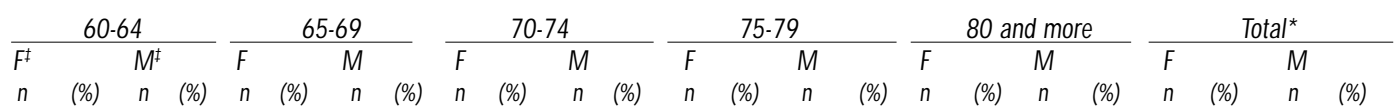

Known hypertensives

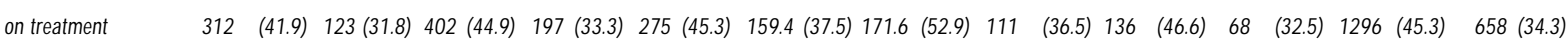
Known hypertensives

\begin{tabular}{llllllllllllllllllllllll}
\hline not treated & 16 & $(2.2)$ & 2 & $(0.5)$ & 16 & $(1.8)$ & $13.9(2.3)$ & 17.3 & $(2.8)$ & 4 & $(0.9)$ & 7 & $(2.2)$ & 5 & $(1.6)$ & 0.3 & $(0.1)$ & 0.1 & $(0.04)$ & 57 & $(1.2)$ & 25 & $(1.3)$
\end{tabular}

\begin{tabular}{lllllllllllllllllllllllll}
\hline Newly diagnosed & 27.9 & $(3.8)$ & 33 & $(8.5)$ & 39 & $(4.4)$ & 37 & $(6.3)$ & 34 & $(5.6)$ & 34 & $(8.0)$ & 15 & $(4.6)$ & 23 & $(7.6)$ & 18 & $(6.2)$ & 13 & $(6.2)$ & 133 & $(4.6)$ & 140 & $(7.3)$
\end{tabular}

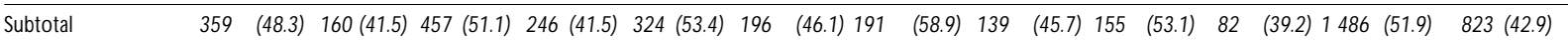

\begin{tabular}{|c|c|}
\hline Normotensive & $386.3(51.9)$ \\
\hline
\end{tabular}

\begin{tabular}{lllllllllll}
\hline Total & 743 & 386 & 895 & 592 & 607 & 425 & 324 & 304 & 292 & 209
\end{tabular}

* Total not adjusted

$\ddagger \mathrm{F}=$ female, $\mathrm{M}=$ male 
Table II

\section{General Characteristics IN HYPertensive AND NORMOTENSIVE SUBJECTS. Mexico City, Mexico, 1998}

$\begin{array}{lcc}\text { Variables } & \begin{array}{c}\text { Non hypertensives } \\ n=2468 \\ \%\end{array} & \begin{array}{c}\text { All Hypertensives } \\ n=2309 \\ \%\end{array} \\ \begin{array}{l}\text { Age } \\ \quad \text { Mean age in years (SD) }\end{array} & 69.9(7.1) & 70.3(6.9) \\ \begin{array}{l}\text { Gender } \\ \text { Female }\end{array} & & \\ & 55.7 & 64.4\end{array}$

Highest education level

\begin{tabular}{lrr} 
Primary & 56.5 & 57.1 \\
\hline Secondary/Technical & 13.6 & 13.2 \\
\hline High school & 2.3 & 2.0 \\
\hline College/more & 5.2 & 4.7 \\
\hline N one & 22.2 & 22.8 \\
\hline Missing & 0.4 & 0.6
\end{tabular}

Marital status

\begin{tabular}{lrr} 
Married & 64.7 & 60.7 \\
\hline Single & 4.4 & 3.8 \\
\hline Divorced & 3.5 & 3.6 \\
\hline W idowed & 26.9 & 30.6 \\
\hline Missing & 0.4 & 0.6
\end{tabular}

Lifestyle risk factors

\begin{tabular}{lll} 
N o physical activity & 77.4 & 79.4 \\
\hline Current smoking & 19.1 & $11.4^{\ddagger}$
\end{tabular}

Clinical risk factors

\begin{tabular}{lcc} 
Diabetes & 20.7 & $25.8^{\ddagger}$ \\
\hline Angor pectoris & 1.0 & $2.6^{\ddagger}$ \\
\hline Acute myocardial infarction & 3.0 & $5.4^{\ddagger}$ \\
\hline Renal failure & 1.0 & 1.6 \\
\hline Hypercholesterolemia & 8.0 & $13.0^{*}$
\end{tabular}

* Known hypertensives + diagnosed through screening

₹ $p$ value $\leq 0.0005$

hypertension. There was no significant difference in the mean age or educational level between the groups. More women than men were hypertensive, and this group also had fewer married and more widowed subjects, probably due to the greater number of females. The non-hypertensive group included significantly more smokers $(19.1 \%$ vs. $11.4 \%)$ ( $\leq £ 0.01)$, while the hypertensive group reported significantly more co-morbidity. The hypertensive group was further divided into three sub-groups: newly-diagnosed participants $(\mathrm{n}=273)$, previously known hypertensives on treatment $(n=1954)$, and previously known hypertensives not on treatment $(\mathrm{n}=82)$. Of those known hypertensives on treatment, $1399(68.5 \%)$ had a blood pressure reading of less than $160 / 90 \mathrm{~mm} \mathrm{Hg}$, and this was also the case for $59(72 \%)$ of the known hypertensives not on treatment (Table III). An isolated elevated diastolic blood pressure reading ( $\geq 90 \mathrm{~mm} \mathrm{Hg}$ ) was found in 157 participants $(57.5 \%)$ in the new diagnosis group, but in less than $15 \%$ of the known hypertensives with or without treatment. Isolated systolic hypertension $(\geq 160 \mathrm{~mm}$ $\mathrm{Hg}$ ) was less frequent; $24.5 \%$ in the new diagnosis group, $8.4 \%$ in the known hypertensives on treatment, and $7.3 \%$ in the group without treatment (Table III). A total of $16.5 \%$ of those with seating blood pressure readings higher than $160 / 90 \mathrm{~mm} \mathrm{Hg}$ had standing hypotension.

Among those participants receiving antihypertensive treatment, $1556(79.6 \%)$ were taking a single drug and only $38(1.9 \%)$ were taking three or more drugs (Table IV). The most common single treatment was an angiotensin-converting enzyme (ACE) inhibitor (53.9\%). Among those receiving two drugs, a common combination was a diuretic with an ACE inhibitor $(13.3 \%)$ (Table IV).

\section{Discussion}

Hypertension is common among elderly people and is accompanied by a high risk of cardiovascular disease. This paper reports the first study of hypertension in elderly people in Mexico, and describes the prevalence of, and treatment for hypertension, in a representative sample. Other studies in Mexico have found a prevalence of hypertension between $4.7 \%$ and $29.2 \%$

Table III

BLOOD PRESSURE READINGS IN THE HYPERTENSIVE GROUP BY DIAGNOSIS AND TREATMENT. Mexico City, Mexico, 1998

\begin{tabular}{|c|c|c|c|c|}
\hline Blood pressure & $\begin{array}{c}\text { New } \\
\text { diagnosis }\end{array}$ & $\begin{array}{c}\text { Known } \\
\text { hypertensives }\end{array}$ & $\begin{array}{c}\text { Known } \\
\text { hypertensives }\end{array}$ & $\begin{array}{c}\text { Total } \\
\text { hypertensives }\end{array}$ \\
\hline & $n=273 \%$ & $n=1954 \%$ & $n=82 \%$ & $n=2309 \%$ \\
\hline$<160 / 90$ & - & 133968.5 & 5972.0 & $1398 \quad 60.6$ \\
\hline D iastolic $\geq 90$ & $157 \quad 57.5$ & $283 \quad 14.5$ & 1113.4 & $451 \quad 19.5$ \\
\hline Systolic $\geq 160$ & $67 \quad 24.5$ & 165 & $\begin{array}{ll}6 & 7.3 \\
\end{array}$ & $238 \quad 10.3$ \\
\hline$\geq 90+\geq 160$ & $49 \quad 17.9$ & 167 & $\begin{array}{ll}67.3 \\
\end{array}$ & 222 \\
\hline
\end{tabular}

salud pública de méxico / vol.43, no.5, septiembre-octubre de 2001 


\section{Table IV \\ Number AND tYPES OF DRUGS USED IN THOSE WITH known hypertension. Mexico City, MeXico, 1998}

\begin{tabular}{lrc} 
Number of drugs & $\mathrm{N}=1954$ & $\%$ \\
O ne & 1556 & 79.6 \\
\hline ACE inhibitors & 839 & 53.9 \\
\hline Beta blockers & 270 & 17.4 \\
\hline Calcium antagonist & 308 & 19.9 \\
\hline Diuretics & 35 & 2.2 \\
\hline Others & 104 & 6.6
\end{tabular}

\begin{tabular}{lrr} 
Two & 360 & 18.4 \\
\hline Diuretic+ACE inhibitors & 48 & 13.3 \\
\hline Diureutic+Beta blockers & 32 & 8.8 \\
\hline Diuretic+Calcium antagonists & 32 & 8.8 \\
\hline Others & 112 & 69.1
\end{tabular}

Three

35

1.8

Four

3

0.15

of the overall adult population..$^{12-14}$ However, none of these studies has focused on people aged over 60 years. In the United States, the National High Blood Pressure Education Program Working Group ${ }^{15}$ found a prevalence of hypertension (defined as systolic blood pressure above $140 \mathrm{~mm} \mathrm{Hg}$ and/or diastolic blood pressure above $90 \mathrm{~mm} \mathrm{Hg}$ ) of approximately $40 \%$ in a subgroup of people aged 65 years or more.

We found that almost half (48\%) of the elderly population is hypertensive (defined as a systolic equal to or above $160 \mathrm{~mm} \mathrm{Hg}$ and/or a diastolic equal to or above $90 \mathrm{~mm} \mathrm{Hg}$ or as self-reported hypertension). Of those people who were previously known as hypertensive, 39\% did not have adequate control of their blood pressure, that is, they had levels of blood pressure equal to or higher than $160 / 90 \mathrm{~mm} \mathrm{Hg}$. This figure is similar to that found for the age group of 60 to 69 years old in the National Survey of Chronic Disease. ${ }^{3}$ Lerman et al $^{16}$ reported a prevalence of hypertension (defined as a systolic above $160 \mathrm{~mm} \mathrm{Hg}$ and a diastolic equal to $90 \mathrm{~mm} \mathrm{Hg}$ ) of almost $50 \%$ in both males and females in the group aged 60 years and more. Even with the limitations imposed by the sample size of the study, they found similar data.

One of the strengths of this study was the accurate measurement of blood pressure. External factors and factors related to the measurement technique, such as posture, cuff size, and equipment were care- fully controlled. ${ }^{10}$ While there was a risk of overestimating the proportion of new hypertensives by using measurements taken on a single occasion, this risk was decreased because the blood pressure measurements were made at home. Almost all trials of pharmacological treatment ${ }^{17-20}$ have made repeated measurements, but none of them have measured the blood pressure in the patient's home. Stergiou et al ${ }^{21}$ studied 189 hypertensive patients and found that the mean blood pressure measured at home was lower than the mean clinic blood pressure by $5.1 \mathrm{~mm} \mathrm{Hg}$ on average, in both systolic and diastolic blood pressure readings $(p<0.001)$.

A high percentage $(96 \%)$ of those known to be hypertensive were receiving pharmacological treatment, although nearly a third of those on treatment (32\%) had blood pressure levels equal to or higher than $160 / 90 \mathrm{~mm} \mathrm{Hg}$, and a further significant proportion had levels higher than $140 / 90 \mathrm{~mm} \mathrm{Hg}$. A small number $(n=59)$ of participants had been diagnosed as hypertensive, but were not on treatment and had blood pressure values below $160 / 90 \mathrm{mmHg}$; this group may have been incorrectly diagnosed.

Nearly $6 \%$ of the people screened were unaware of being hypertensive before screening. This proportion of new hypertensives is small in comparison with that reported in other studies. In the 1994 Health Survey for England, 38\% of people aged 65 years and older had a previously unknown diagnosis of hypertension. ${ }^{22}$ In the National Survey of Chronic Diseases, ${ }^{3}$ $25 \%$ of people aged 60 to 69 years had a previously unknown diagnosis of hypertension. The reason for the difference between the National Survey and this study may be that the population included in this study is covered by the Social Security healthcare system and regularly attends family medicine units. The average number of consultations at IMSS is 2.9 per year in this group of age, higher than that for the population at large, ${ }^{2}$ therefore, the former group had a greater chance to be diagnosed.

Overall, physicians prescribed more expensive hypertensive drugs (ACE inhibitors, beta-blockers, and calcium antagonists), rather than the first election drug, diuretics, which were prescribed to only $2 \%$ of patients. In those being prescribed two drugs, one of the least frequent combinations was a diuretic with a beta-blocker (9\%). The excessive prescription of captopril, for instance, imposes a high financial burden on healthcare services. Although patients do not pay directly for the drugs, it is important that family physicians realize that diuretics are both cheaper and clinically better for the patient. The quality of care provided by family physicians to elderly people should be an area of future research. 
We were surprised to find a number of highly qualified nurses who were not using the correct technique to measure blood pressure when they were first observed. Future programs for hypertension control in Mexico must begin with careful training in the techniques of measurement.

The implications of the high percentage of hypertensive people in the elderly population are important at two levels. At the individual level it is important to consider the impact on quality of life, the complications and drug therapy, and the economic burden of the disease. At the institutional level, the expected increase in utilization rates of those with hypertension, stroke, and other cardiovascular diseases will put a considerable strain on the system at the primary, secondary, and tertiary levels of care.

\section{Acknowledgements}

Our gratitude to the participants and to the supervisor team, computer officers, and nurses of the Medical Research Unit on Ageing.

\section{References}

1.Pan A merican Health $O$ rganization. Health in the Americas.W ashington, D.C.:PAHO, 1998.

2. Reyes S. Envejecimiento poblacional en el IMSS. Implicaciones económicas y de políticas de salud (PhD Thesis) Londres: London School of Hygiene and Tropical Medicine, Health Policy Unit.

3. Secretaría de Salud. Boletín de Información Estadística, Recursos y Servicios. México: SSA; 1995

4. Secretaría de Salud. Encuesta $N$ acional de Enfermedades Crónicas. México, D.F.: Dirección General de Epidemiología, 1996.

5. World Health O rganization. World Health Statistics Annual. Ginebra: W HO; 1986-1995.

6. 1999 W orld Health 0 rganization-International Society of Hypertension Guidelines for the Management of Hipertension. Guidelines Subcommittee. J Hypertens 1999;17:151-183.

7. MacMahon S, Peto R, Cutler J, Collins R, Sorlie P, N eaton J et al. Blood pressure, stroke, and coronary heart disease.Part 1 , prolonged differences in blood pressure: Prospective observational studies corrected for the regression dilution bias. Lancet 1990;335:765-774.

8. Ebrahim S, Davey-Smith G. Health promotion in older people for the prevention of coronary heart disease and stroke. Health promotion effectiveness reviews. Londres: Health Education Authority, 1996.

9. Kaplan N . C linical Hypertension. Baltimore (MD):W illiams and W ilkins, 1998.

10. 0 Brien E, Petrie J, Littler W, de Swiet M, Padfield P, Dillon M et al. Blood pressure measurement. Recommendations of the British Hypertension Society. Londres: British Medical Journal Publishing Group, 1997. 11. Messerli F. 0 sler s Manoeuvre, pseudohypertension, and true hypertension in the elderly. Am J Med 1986;80:907-910.

12. Rodríguez GC, Hughes F, Hamsho P,Aubry P. Estudio estadístico de la presión arterial en derechohabientes del IMSS en Veracruz.Arch Inst $C$ ardiol Mex 1982;52:425.

13. González CA, Cooper R. A blood pressure survey in N uevo Laredo, México. Public Health Rep 1982;97:116.

14. Yamamoto-Kimura L, Zamora-González J, G arcía de la Torre G, C ardoso $G$, Fajardo $A, A$ yala $C$ et al. Prevalence of high blood pressure and associated coronary risk factors in an adult population of Mexico City. Arch Med Res 1998:29:341-349.

15. N ational High Blood Pressure Education Program. W orking group report on hypertension in the elderly. Hypertension 1994;23:275-285

16. Lerman I,Villa A, Llaca-Martínez C , C ervantes-Turrubiatez L, A guilarSalinas $C$, W ong $B$ et al. The prevalence of diabetes and associated coronary risk factors in urban and rural older Mexican populations. J Am Ger Soc 1998:46:1387-1395.

17. SHEP C 0-operative Research Group. Prevention of stroke by antihypertensive drug treatment in older persons with isolated systolic hypertension. JAMA 1991;265:3255-3264.

18.W helton P,A ppel L. Espeland M,A ppelgateW, Ettinger W, Kostis J et al. Sodium reduction and weight loss in the treatment of hypertension in older persons. A randomized controlled trial of nonpharmacologic interventions in the elderly (TO NE). JAMA 1998;279:839-846.

19. Staessen J, Fagard R, Thijs L, C elis H,A rabidze G G, Birkenhager W H et al. Randomised double-blind comparison of placebo and active treatment fot older patients with isolated systolic hypertension. Lancet 1997;350: 757-764.

20. Lisheng L, Guang W ang J, G ong Lansheng, G ouzhang L, Staessen J for the Systolic Hypertension in China (syst-China) Collaborative Group. Comparison of active treatment and placebo in older $\mathrm{C}$ hinese patients with isolated systolic hypertension.J Hypertens 1998;16:1823-1829.

21. Stergiou G, Skeva I, Zourbaki A, Mountokalasi T, Self-monitoring of blood pressure at home: How many measurements are need? J Hypertens 1998;16:725-731.

22. Colhoun HM, D ongW, Poulter N R. Blood pressure screening, management and control in England: Results from health survey for England 1994. J Hypertens 1998;16:747-752. 